\title{
Francisco José Alfaro Pérez, Zaragoza 1564, el año de la peste, Institución „Fernando el Católico”, Colección de Letras, Zaragoza 2019, ss. 151 + kolorowe ilustracje, grafiki
}

Crancisco José Alfaro Pérez jest historykiem pracującym w Departamen1 cie Historii Nowożytnej i Najnowszej Uniwersytetu w Saragossie (Hiszpania). W swoich badaniach skupia się głównie na kwestiach społecznych w epoce nowożytnej, ze szczególnym uwzględnieniem historii miasta Saragossy. W ostatnim czasie opublikował - jako autor, współautor i redaktor kilka książek w języku hiszpańskim: Tiempos de mudanza. La instauración de la Nueva Planta borbónica en la ciudad de Zaragoza (1707-1715)1 („Czasy zmian. Wprowadzenie burbońskich dekretów Nueva Planta w mieście Saragossa (1707-1715)"); Dispensas matrimoniales de la Diócesis de Zaragoza, siglos XV al XIX² („Dyspensy małżeńskie w diecezji Saragossa, wieki XV do XIX”) czy Cuando la frontera era el Sur. Europa Suroccidental, siglos XVI$-X X^{3}$ („Kiedy granicą było Południe. Europa Południowo-Zachodnia, wieki XVI-XX”). Recenzowana książka jest następną publikacją tego autora poświęconą konkretnemu wydarzeniu historycznemu, do którego doszło w Saragossie. Powstała ona w ramach projektu badawczego „Od gminy do

1 F. J. Alfaro Pérez, Tiempos de mudanza. La instauración de la Nueva Planta borbónica en la ciudad de Zaragoza (1707-1715), „Cuadernos de Aragón” 66, Zaragoza 2017.

2 F. J. Alfaro Pérez, J. R. Royo García, Dispensas matrimoniales de la Diócesis de Zaragoza, siglos XV al XIX, „Fuentes Históricas Aragonesas”, Zaragoza 2018.

3 F. J. Alfaro Pérez (coord.), Cuando la frontera era el Sur. Europa Suroccidental, siglos XVI-XX, Zaragoza 2019. 
rodziny w Aragonii nowożytnej" oraz grupy badawczej historii nowożytnej, których jest członkiem ${ }^{4}$. Tym razem Alfaro Pérez podjął się próby rekonstrukcji wydarzeń towarzyszących epidemii dżumy w tym aragońskim mieście, która wybuchła w 1564 r. i okazała się „jedną z najbardziej śmiertelnych epidemii w historii miasta” (s. 111).

Książka składa się z wykazu skrótów, wstępu autorstwa José Antonio Salasa Ausensa, wprowadzenia, pięciu rozdziałów, zakończenia, fragmentów źródeł, do których autor odwołuje się w swojej narracji, bibliografii oraz indeksu nazw i osób.

Punktem wyjścia rozważań autora jest dzieło pt. Información y curación de la peste de Çaragoça y praeservación contra la peste en general (,Informacja na temat leczenia dżumy z Saragossy i ogólnej ochrony przed zarazą"), autorstwa Juana Tomasa Porcella, lekarza pochodzącego z Sardynii i naocznego świadka ówczesnych wydarzeń, opublikowane 22 marca 1565 r. w drukarni Maríi de Solórzano w Saragossie. Porcell detalicznie przedstawił w nim wszelkie kwestie związane z genezą i przebiegiem dżumy w Saragossie oraz działania podjęte przez władze miasta, aby jej skutecznie przeciwdziałać. Alfaro Pérez postanowił potwierdzić, porównać i zbadać informacje znajdujące się u Porcella w możliwie kompleksowy sposób, co miało przyczynić się do pełniejszego ukazania zmagań miasta z czarną śmiercią (s. 20). W tym celu wykorzystał różnorodne źródła archiwalne z tamtego okresu, w których znajdują się informacje odnoszące się do tytułowej epidemii. Szczególnie pomocne okazały się dla niego zwłaszcza te znajdujące się w Archiwach Municypalnym i Diecezjalnym w Saragossie, Archiwum Protokołów Notarialnych w Saragossie, a także w archiwach parafialnych i notarialnych z obszaru doliny rzeki Ebro (z obszaru Aragonii, Katalonii i Nawarry). Próba skonfrontowania informacji zawartych w dziele Porcella z tymi umieszczonymi w innych, niezależnych źródłach z epoki zasługuje na pochwałę. Dzieło Sardyńczyka przez długi czas pozostawało bowiem najważniejszym źródłem do poznania tamtych tragicznych wydarzeń rozgrywających się w tym aragońskim mieście. Perspektywa badawcza przyjęta przez autora miała na celu nie tylko uaktualnienie wiedzy o dżumie

4 „Del concejo a la familia en el Aragón moderno” HAR 2016-75899-P; el Grupo de Investigación de Referencias Blancas (de Historia Moderna) H01_17R. 
w mieście, lecz także weryfikację i potwierdzenie bądź podważenie informacji na jej temat mieszczącyh się u Porcella. Co istotne, autor nie pretenduje swoją książką do definitywnych wniosków, wprost przeciwnie - pragnie zwrócić uwagę na konieczność dalszych badań nad wieloma szczegółowymi wątkami związanymi z dżumą w Saragossie i w innych miejscach położonych w dolinie rzeki Ebro. Jego książka może zatem odgrywać rolę katalizatora nowych badań w tym zakresie.

Aby wzbudzić zainteresowanie współczesnego czytelnika tematem swojej książki, Alfaro Pérez zestawia opisywaną przez siebie dżumę z XVI w. ze współczesnymi przypadkami jej występowania, jakie odnotowano na Madagaskarze (2017) i w Stanach Zjednoczonych (2019). Autor, powołując się na dane Światowej Organizacji Zdrowia, podaje, że w latach 2010-2015 na świecie odnotowano 3248 przypadków dżumy, z których 584 okazały się śmiertelne. Jak stwierdza: „[...] czarna śmierć nadal istnieje, tak samo jak dawniej, z tą różnicą, że dziś wzbudza mniej strachu" (s. 30).

Autor $\mathrm{w}$ rozdziale pierwszym przedstawia również teorie na temat geograficznego pochodzenia czarnej zarazy i jej najważniejsze rodzaje oraz wskazuje na źródła jej powstawania i rozprzestrzeniania się w ludzkim organizmie. Omawiając te zagadnienia, przytacza najnowsze ustalenia badaczy z Norwegii i Włoch, według których samo zarażenie się przez człowieka dżumą nie było spowodowane wyłącznie ugryzieniem przez pchły czy inne insekty, lecz konieczne były dodatkowe czynniki, wśród których do najważniejszych należały brud, stan zdrowia oraz inne pasożyty znajdujące się w jego ciele (s. 29). Innymi czynnikami zwiększającymi ryzyko zakażenia były osłabienie źle odżywiających się organizmów oraz ograniczenia ówczesnej medycyny (s. 34).

W rozdziale drugim autor, powołując się na Porcella, przytacza rozpowszechnioną hipotezę, zgodnie z którą za dżumę w Saragossie odpowiedzialni byli francuscy kupcy. Zgodnie z jego relacją w wyniku dżumy w mieście życie miało wówczas stracić 10000 osób. Z rozważań autora wynika jednak, że być może mamy tutaj do czynienia ze strategią przypisywania tego, co złe, obcym: Żydom, Moryskom, odmieńcom, w tym konkretnym przypadku Francuzom (s. 45-46). Alfaro Pérez jest w tej kwestii ostrożny, zwracając uwagę na dwie kwestie: po pierwsze, kiedy w Saragossie wybuchała dżuma, w innych miejscach w Aragonii, takich jak Calamocha, 
Tarazona i doliny Ebro, np. Ribera de Nawarra, jej faza krytyczna była już przezwyciężona; po drugie, aragońskie miasta i miejscowości odnotowują spadek spisów chrztów jeszcze przed 1564 r., co może świadczyć o wcześniejszym pojawieniu się dżumy i innym źródle jej pochodzenia (s. 46-48). Podobnie w kwestii liczby umarłych autor podkreśla, że nie jest do końca pewne, czy epidemia kosztowała miasto życie 10000 osób między marcem a październikiem ${ }^{5} 1564$ r., nie dysponujemy bowiem odpowiednimi materiałami źródłowymi, które mogłyby to potwierdzić, a w tych, które są dostępne, nie wszystko zostało zapisane (vide luki w spisach parafialnych i notarialnych, np. w parafii San Gil - s. 58). Podążając jednak tropem Porcella, należy stwierdzić, że autor wylicza, że Saragossa liczyła wówczas ok. 25 000-30 000 mieszkańców, co może oznaczać, że życie w wyniku dżumy straciło ok. 33-40\% mieszkańców miasta (s. 61). Rozważania autora pokazują, że dokładny i całościowy przebieg epidemii wymyka się historykom z uwagi na braki w materiale źródłowym, co jednocześnie nakazuje krytyczne podejście do dzieła Porcella. Nastroje społeczne, jakie towarzyszyły ludziom w związku z wszechobecnością zarazy morowej, najlepiej oddaje poniższy fragment rozważań autora:

Dżuma mogła znajdować się wszędzie: w domu, na rogu, w zagrodzie, w szkole, w stodole, w kościele, czy na cmentarzu i nikt i nic nie mogło przewidzieć jej ataku. W rozpaczy mogła zostać przyniesiona przez starca, pannę, dziewczynkę, duchownego, włóczęgę czy hrabinę [...]. W mentalności ludzi z epoki dżuma pojawiała się i znikała jak fantazmat przyciągany przez wiatr jako kaprys woli lub boskiej sprawiedliwości (s. 55).

W rozdziale trzecim autor kreśli postawę władz miasta wobec epidemii, szczegółowo opisując konkretne działania ${ }^{6}$. Wśród nich do najważniejszych należało utworzenie specjalnego miejsca (Casa lub Torre de los convalecientes) dla zarażonych, znajdującego się poza miastem; podpi-

5 Dżuma pojawiła się w Saragossie w lutym tego roku, liczba zakażonych osiągnęła swój punkt kulminacyjny w maju i czerwcu, a jej powolny zanik daje się zauważyć w październiku (s. 56).

${ }^{6}$ Jak podaje autor, walka władz miasta z epidemią dżumy była prowadzona w trzech obszarach: w mieście, w szpitalu oraz w izolatce poza miastem (s. 111). 
sanie kontraktu z osobami z Francji (z Tuluzy i Montpellier), którzy za wynagrodzenie podjęli się przybycia do Saragossy i pomocy w oczyszczaniu mieszkań zakażonych; oznaczanie herbami miasta wraz z adnotacją drzwi wejściowych domów, których mieszkańcy umarli w trakcie epidemii lub opuścili miasto; spisywanie inwentarzy posiadanych przez nich rzeczy, aby uchronić te domy przed rabunkiem; czyszczenie rzeczy zakażonych w rzece przez cztery dni i późniejsze suszenie ich na słońcu, co w powszechnej opinii przywracało im czystość i uwalniało od zakażenia; mycie i wietrzenie domów czy czasowy zakaz sprzedaży ubrań z Saragossy do innych miast (s. 68-74). W tej części rozważań autor odwołuje się do dwóch ważnych materiałów archiwalnych: oryginału wspomnianego kontraktu z Francuzami z 10 grudnia 1564 r. znajdującego się w Archiwum Municypalnym w Saragossie oraz kopii memoriału miasta Saragossa do miasta Burgos z 4 października 1565 r., w którym aragońskie władze zalecały Kastylijczykom, co należy czynić, aby oczyścić miasto z dżumy (oba dokumenty zostały umieszczone przez autora w wykazie źródeł, który znajduje się na końcu książki).

W rozdziale czwartym autor przedstawia postać Porcella, określając go jako jednego z nielicznych lekarzy i bohaterów, którzy przyjęli wołanie miasta o pomoc w walce $\mathrm{z}$ chorobą. Zaletą tej części rozważań jest przywołanie przez autora fragmentów dzieła Porcella, które nie tylko dają próbkę szczegółowego opisu epidemii, lecz również ukazują powstały na jej podstawie konflikt społeczny (s. 81-92). Jego egzemplifikację otrzymujemy w rozdziale piątym, w którym Alfaro Pérez ukazuje czytelnikowi postać prawnika Joana Baptisty Sali, przysięgłego miasta w roku dżumy i jednego z bohaterów w walce z epidemią, który złożył skargę w Kortezach Generalnych na władze miasta z powodu długu, który w jego przekonaniu został na niego niesłusznie nałożony (s. 111). Kopia jego memoriału również figuruje w materiałach archiwalnych na końcu książki.

Reasumując, recenzowana książka stanowi cenne, krytyczne opracowanie epidemii dżumy, jaka nawiedziła Saragossę w drugiej połowie XVI w. Autor, opierając się na materiałach archiwalnych, uzupełnił i skorygował podstawowe źródło do opisywanych wydarzeń, jakim jest XVI-wieczne dzieło Juana Tomasa Porcella. Z całą pewnością zaletą pracy Alfaro Péreza jest dobre wykorzystanie warsztatu historyka i przyjęta przez niego 
metodologia. Mimo wyznaczenia nowych tropów w analizowanym zagadnieniu autor jest świadomy potrzeby dalszych badań, których efekty moga zwiększyć stan aktualnie posiadanej wiedzy na temat tego tragicznego wydarzenia w dziejach miasta. I choć w niektórych momentach recenzowana książka mogłaby być nieco bardziej rozbudowana (np. w kwestii biografii Porcella i jego dzieła), wydaje się, że autorowi zależało na syntetycznym ujęciu tematu i wierności rygorowi naukowemu, który nie pozostawia miejsca na spekulacje, czasami atrakcyjne i kuszące, ale jednak niewnoszące niczego nowego i wartościowego do nauki. W tym sensie syntetyczność i zwięzłość książki przesądzają o jej naukowości.

Filip Kubiaczyk (Poznań-Gniezno) Nr ORCID: 0000-0003-4124-6480

\section{Katarzyna Kuras, Dwór królowej Marii Leszczyńskiej. Ludzie, pieniądze i wptywy, Towarzystwo Wydawnicze „Historia Iagellonica”, Kraków 2018, ss. 337}

Tematem tej interesującej książki jest szeroko pojęte funkcjonowanie 1 dworu królowej francuskiej Marii Leszczyńskiej, córki niefortunnego polskiego monarchy Stanisława Leszczyńskiego. Przy tej okazji autorka 